\title{
EFFECT OF B-SITOSTEROL AND GIBBERELLIC ACID ON LEAF ANGLE ,GROWTH, FLOWERING AS WELL AS BIOCHEMICAL CONSTITUENTS OF MARIGOLD (Calendula officinalis) PLANT
}

Rashad, E. M.; M.S.A. Abd El-Wahed and A.A. E. Amin

Botany Department, National Research Centre, Dokki, Cairo, Egypt

\begin{abstract}
Marigold plant growth and orientation were improved by adding gibberellic acid (25, 50 and $\left.100 \mathrm{mgL}^{-1}\right)$ and $\beta$-sitosterol $\left(20,40\right.$ and $\left.80 \mathrm{mgL}^{-1}\right)$ as well as their interaction treatments. $\mathrm{GA}_{3}\left(25 \mathrm{mgL}^{-1}\right)$ was more effective on number of branches, fresh and dry weight of shoots and roots/plant. While, $\mathrm{GA}_{3}\left(100 \mathrm{mgL}^{-1}\right)$ significantly increased plant height. Leaf angle was more decreased with $\mathrm{GA}_{3}$ than $\beta$-sitosterol application. Both $\mathrm{GA}_{3}\left(100 \mathrm{mgL}^{-1}\right)$ or $\beta$-sitosterol $\left(40 \mathrm{mgL}^{-1}\right)$ significantly induced flowering earliness and number of marigold plant inflorescences. While low concentration of both substances improved the other characters of inflorescences. $\mathrm{GA}_{3}\left(100 \mathrm{mgL}^{-1}\right)$ and $\beta$ sitosterol $\left(40 \mathrm{mgL}^{-1}\right)$ interaction significantly increased earliness, number and stalk length of marigold plant inflorescences.

Pigments (Chl.a \& b and carotenoids) and biochemical constituents (total sugars, indoles and free amino acids) were significantly enhanced with $\mathrm{GA}_{3}(25 \mathrm{mgL}$ $\left.{ }^{1}\right)$ and / or $\beta$-sitosterol $\left(20\right.$ or $\left.40 \mathrm{mgL}^{-1}\right)$ as foliar application. However, both the highest concentration of two bioregulators gave the highest phenolic content of marigold plant leaves. Additionally, $\mathrm{GA}_{3}\left(25 \mathrm{mgL}^{-1}\right)$ and $\beta$-sitosterol $\left(40 \mathrm{mgL}^{-1}\right)$ interaction was more effective on leaves biochemical contents (Chl.a, carotenoids, total sugars, indols and free amino acids). Phenolic content was permanent increased with the highest concentration of both growth substances. $\mathrm{GA}_{3}$ and $\beta$-sitosterol appeared positive correlation between fresh weight of inflorescences and Chl. $(a+b)$. All the results were significantly negative attributed with phenolic content of marigold plant leaves.
\end{abstract}

Keywords: Marigold, Gibberellic acid, $\beta$-sitosterol, growth orientation, biochemicals.

\section{INTRODUCTION}

Marigold plant (Calendula officinalis L.) is a common herb, has some compounds that have a number of medicinal uses. Sterols are one of the present compounds in marigold plant.

Plant sterol composition varies within different species and physiological stage of development (Ebrahimzadeh et al., 2001). Despite the identification of plant steroids (Brs), dozens of other sterols are also found in plants. Major plant sterols such as sitosterol and stigmasterol are similar in structure of the fungal ergosterol and cholesterol in animals. Sterols are known to regulate transcriptional and post transcriptional events, which in turn affect lipid synthesis, meiosis, apoptosis, developmental patterning, protein cleavage and protein degradation (Edwards and Enricsson, 1999), carbohydrate distribution in maize (Abd El-Wahed, 2000), free amino acids, phenols and indoles in soybean (Abd El-Wahed, 2008). In addition, brassinosteroids could be generate erect leaf of rice plant (Morinaka et al., 2006). 
Rashad, E. M. et al.

GAs regulate various developmental processes throughout the life cycle of the plant, from seed germination through leaf expansion, stem elongation, flower induction and development to seed development (Sun and Gubber, 2004). GAs changed the orientation of lateral branches of runners to that of erect ones. The amount of native gibberellic acid antagonists was higher in runner plants. Furthermore, runner plants contained a particular gibberellic acid inhibitor not found in erect plants. Addtionally, gibberellic acid changes leaf orientation and prostate growth habit of short-day plant to that typical of the long-day and modifies leaf sharp in both types of plants. Geotropic responses of the stem appear to be modified by photoperiod, temperature and gibberellic acid (Wallenstein and Luke, 1963). Robust target genes are affected specifically by a single hormone. However, in the cases of GA induced genes, no specific robust targets were identified. This may suggest that interactions with other hormones play major roles in GA action which necessitates the existence of efficient and sensitive crosstalk mechanisms among the corresponding signaling pathways (Nemhauser et al., 2006).

\section{Purpose of the present study:}

While some studies claimed that $\mathrm{GA}_{3}$ and steroids promote plant growth. However none of these studies have sought to examine $\beta$-sitosterol and $\mathrm{GA}_{3}$ as single or combination on growth to obtain quantitative data on the actual characters of marigold plant. The purpose of the present study was to determine the effect of $\beta$-sitosterol and $\mathrm{GA}_{3}$ on growth, leaf orientation, flowering as well as chemical contents of marigold plant.

\section{MATERIALS AND METHODS}

Greenhouse experiments were carried out at the National Research Centre, Cairo, Egypt, during two successive seasons (2005-2006, 20062007 ) to study the effect of foliar application of different concentrations of gibberellic acid (Diterpene) and $\beta$-sitosterol (Triterpene) as well as their combinations on growth, flowering and some biochemical constituents of marigold plant. Carotenoids of Calendula officinalis/ L. plant is Tetraterpene. Seeds were obtained from Medicinal and Aromatic plants Research Section, Ministry of Agriculture. Seeds were sown in bed on October $15^{\text {th }}$ for both the two seasons. After one month, the uniform seedlings about $6 \mathrm{~cm}$ in height with 2 pairs of leaves were individually transplanted into pots of $30 \mathrm{~cm}$ diameter filled with $10 \mathrm{~kg}$ clay-loamy soil. The plants were fertilized with 2.5 (g) ammonium sulphate $+3.75(\mathrm{~g})$ calcium super phosphate $+1.25(\mathrm{~g})$ potassium sulphate per pot after 3 weeks from transplanting and repeated again after 2 weeks later.

Plants were foliar sprayed with gibberellic acid $\left(\mathrm{GA}_{3}\right)$ at $(0,25,50$ or $100 \mathrm{mg} / 1), \beta$-sitosterol at $(0,20,40$ or $80 \mathrm{mg} / \mathrm{l})$ and control plants prayed with distilled water. Plants were twice sprayed with the growth regulators up the run-off occurred, the first sprayed was five weeks after transplanting and the second one was applied three weeks later. Treatments were arranged in 
complete randomized design, replicated 3 times, each replicate contained 6 pots.

Biochemical constituents determination:

After two weeks from the second spray with the growth regulators the fifth leaf from the top of plant was collected for determination of photosynthetic pigments content (Chl.a, Chl.b and total carotenoids) spectrophotometrically as described by Saric et al., (1967). Flowering date was calculated as number of days from sowing to the first flower open. The following data were recorded at the full blooming stage (Apirl 15 th): plant height, number of branches/plant, fresh and dry weights of shoot and root/plant, shoot/root ratio, leaf angle, number of inflorescences/plant, stalk length and diameter of inflorescence as well as average fresh and dry weight of one inflorescene .Samples of ray flowers were air-dried and their carotenoids content was determined using the method described by the A.O.A.C. (1990). In addition, samples of leaves were oven-dried at a temperature of $70^{\circ} \mathrm{C}$ for 24 hours, and their contents of total sugars were determined (Dubois et al.,1956), total indoles (Bently, 1961), phenols (Danial and George, 1972) and free amino acids (Plummer, 1978).

Statistical Analysis:

The data were statistically analyzed for each season and then combined analysis of the two seasons was carried out according to procedure outlined by Snedecor and Cochran (1990). For comparison between means, L.S.D. test at $5 \%$ was calculated.

Simple correlation coefficients between growth, flowering and biochemical contents under studies treatments of $\mathrm{GA}_{3}, \beta$-sitosterol and their interaction were determined according to Gomez and Gomez (1984).

\section{RESULTS AND DISCUSSION}

\section{Effect of $\mathrm{GA}_{3}$ on vegetative growth characters:}

Data in Table (1) and Fig. (1) showed that $\mathrm{GA}_{3}$ significantly increased vegetative growth characters i.e. plant height, number of branches, fresh and dry weight of shoots and roots/plant. While, shoot/root ratio of fresh and dry weight were significantly decreased compared to control. $\mathrm{GA}_{3}\left(100 \mathrm{mgL}^{-1}\right)$ gave the highest value of plant height. GAs cause dramatic increases in plant height (King et al., 2008).

In the same trend, $\mathrm{GA}_{3}\left(25 \mathrm{mgL}^{-1}\right)$ was more effective on number of branches, fresh and dry weight of root and shoot/plant (Table 1). The reduction of leaf angle was attributed to increasing $\mathrm{GA}_{3}$ concentration. These effects might be due to $\mathrm{GA}_{3}$ role for improving vegetative growth characteristic, whereas GAs are plant hormones that participate in regulation of many growth developmental processes in plants (Hedden and Phillips, 2000 and Olszewski et al., 2002).

\section{Effect of $\beta$-sitosterol on vegetative growth:}

$\beta$-sitosterol application led to significant increase in vegetative growth characters (plant height, number of branches, fresh and dry weight of root and shoot) of marigold plant as shown in Table (2) and Fig.(2). Growth 
Rashad, E. M. et al.

characters were significantly differed in their response to $\beta$-sitosterol application. In addition, reducing leaf angle was related with increasing $\beta$ sitosterol concentration. Shoot dry weight and shoot/root rate of plant were more increased by $40 \mathrm{mgL}^{-1} \beta$-sitosterol, while shoot fresh weight and shoot/root ratio of fresh weight were improved by $20 \mathrm{mgL}^{-1} \beta$-sitosterol. The highest number of branches, root fresh weight and leaf angle was recorded with $80 \mathrm{mgL}^{-1} \beta$-sitosterol. The increments of growth criteria might be due to the differentiation of morphogenesis mother cell during plant growth stages as a result to $\beta$-sitosterol application. The results were in agreement with Cao and Chen (1995) who reported that brassinosteroid induced inclination was accompanied by increasing lamina fresh weight. Also, Abd El Wahed et al.,( 2001) showed stimulatory effect on vascular differentiation, thickness of upper epidermal mesophyll tissue layers growth and yield as well as chemical composition of wheat plant by $\beta$-sitosterol application . In addidion, brassinolide doubled the mean root length and the number of mitoses over that controls at low concentration (Howell et al., 2007).

Effect of $\mathrm{GA}_{3}$ and $\beta$-sitosterol interaction on vegetative growth:

Data in Table (3) and Figures ( 3 to 5 ) showed that vegetative characters significantly increased as a result of $\mathrm{GA}_{3}$ and $\beta$-sitosterol interaction application. Their improvements were related to increase both $\mathrm{GA}_{3}$ and $\beta$-sitosterol concentrations. The highest values of vegetative growth characters (number of branches and fresh weight of shoots/plant) was obtained with $\mathrm{GA}_{3}\left(25 \mathrm{mgL}^{-1}\right)$ plus $\beta$-sitosterol $\left(80 \mathrm{gL}^{-1}\right)$, dry weight of shoots/plant with $\mathrm{GA}_{3}\left(25 \mathrm{mgL}^{-1}\right)+\beta$-sitosterol $\left(40 \mathrm{mgL}^{-1}\right)$ and shoot/root ratio with $\mathrm{GA}_{3}\left(25 \mathrm{mgL}^{-1}\right)$ plus $\beta$-sitosterol $\left(20 \mathrm{mgL}^{-1}\right)$ and $\beta$-sitosterol $\left(80 \mathrm{mgL}^{-1}\right)$. It appears from the results that both phytohormones play an important role in differentiation and morphogenesis of plant cell because their precoursor is isoprenoid. In relation, Hedden and Phillips (2000) reported that GAs are plant hormones that participate in regulation of many growth and developmental processes in plants and important in stem regulation.

Table (1): Effect of gibberellic acid and $\beta$-sitosterol on vegetative growth characters of marigold plant during full blooming stage (average of the two seasons).

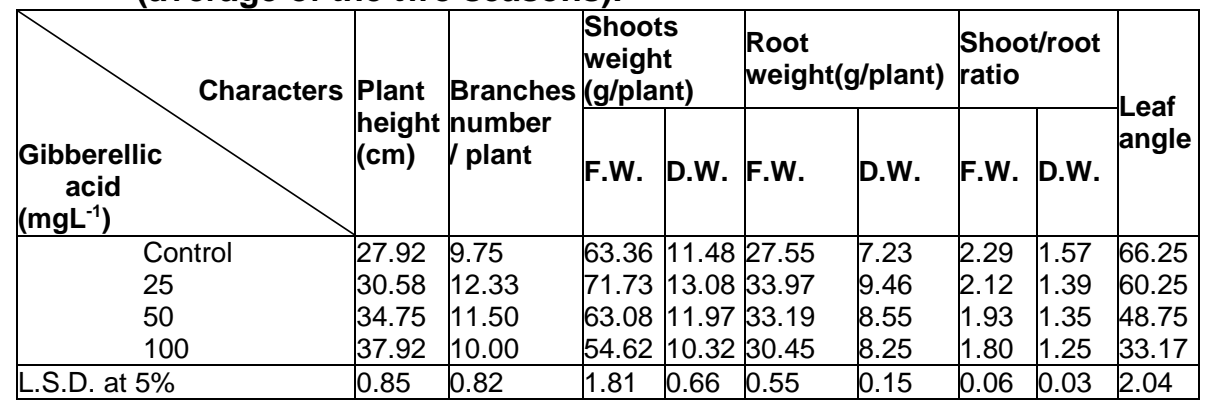


J. Agric. Sci. Mansoura Univ., 33 (11), November, 2008

Fig. (1): Leaf angle of marigold plant under gibberellic acid treatments.

Table (2): Effect of $\beta$-sitosterol on vegetative growth characters of marigold plant during full blooming stage (average of the two seasons)

\begin{tabular}{|c|c|c|c|c|c|c|c|c|c|}
\hline \multirow[b]{2}{*}{$\begin{array}{l}\text { B Sitoster } \\
\left(\mathrm{mgL}^{-1}\right)\end{array}$} & \multirow{2}{*}{$\begin{array}{c}\text { Plant } \\
\text { height } \\
(\mathrm{cm})\end{array}$} & \multirow{2}{*}{$\begin{array}{c}\text { Branches } \\
\text { number } \\
\text { / plant }\end{array}$} & \multicolumn{2}{|c|}{$\begin{array}{c}\text { Shoots } \\
\text { weight } \\
\text { (g/plant) }\end{array}$} & \multicolumn{2}{|c|}{$\begin{array}{c}\text { Root } \\
\text { weight(g/plant) }\end{array}$} & \multicolumn{2}{|c|}{$\begin{array}{l}\text { Shoot/root } \\
\text { ratio }\end{array}$} & \multirow{2}{*}{$\begin{array}{l}\text { Leaf } \\
\text { angle }\end{array}$} \\
\hline & & & F.W. & D.W. & F.W. & D.W. & F.W. & D.W. & \\
\hline Control & 32.25 & 9.00 & 57.96 & 10.68 & 31.32 & 8.42 & 1.87 & 1.27 & 52.83 \\
\hline 20 & 33.25 & 11.08 & 66.93 & 12.59 & 30.42 & 8.3 & 2.2 & & 52. \\
\hline 40 & 34.25 & 11.67 & 66.22 & 13.42 & 31.41 & 8.3 & 2.12 & & 55.00 \\
\hline 80 & 31.42 & 11.83 & 61.68 & 10.17 & 32.45 & 8.35 & 1.95 & 1.23 & 48.42 \\
\hline L.S.D. at $5 \%$ & 0.85 & 0.82 & 1.81 & 0.66 & 0.55 & N.S. & 0.06 & 0.03 & 0.04 \\
\hline
\end{tabular}

Fig. (2): Leaf angle of marigold plant under $\beta$-sitosterol treatment.Table 
Rashad, E. M. et al.

(3): Effect of the interaction between gibberellic acid and $\beta$-stosterol treatments on vegetative growth characters of marigold plant during full blouming stage (average of the two seasons).

\begin{tabular}{|c|c|c|c|c|c|c|c|c|c|c|}
\hline \multirow{2}{*}{\multicolumn{2}{|c|}{$\begin{array}{l}\text { Characters } \\
\text { Interaction } \\
\text { treatments }\end{array}$}} & \multirow{2}{*}{$\begin{array}{c}\text { Plant } \\
\text { height } \\
\text { (cm) }\end{array}$} & \multirow{2}{*}{$\begin{array}{c}\text { Branches } \\
\text { number } \\
\text { / plant }\end{array}$} & \multicolumn{2}{|c|}{$\begin{array}{l}\text { Shoots } \\
\text { weight } \\
\text { (g/plant) }\end{array}$} & \multicolumn{2}{|c|}{$\begin{array}{l}\text { Root weight } \\
\text { (g/plant) }\end{array}$} & \multicolumn{2}{|c|}{$\begin{array}{l}\text { Shoot/root } \\
\text { ratio }\end{array}$} & \multirow{2}{*}{$\begin{array}{l}\text { Leaf } \\
\text { angle }\end{array}$} \\
\hline & & & & F.W. & D.W. & F.W. & D.W. & F.W. & D.W. & \\
\hline \multicolumn{11}{|c|}{\begin{tabular}{|l|l|}
$\mathrm{GA}_{3}\left(\mathrm{mgL}^{-1}\right)$ & $\begin{array}{l}\text { Sitosterol } \\
\left(\mathrm{mgL}^{-1}\right)\end{array}$ \\
\end{tabular}} \\
\hline \multirow{4}{*}{0} & 0 & 22.33 & 7.00 & 47.64 & 8.11 & 27.27 & 7.28 & 1.75 & 1.78 & 77.33 \\
\hline & 20 & 30.00 & 9.00 & 74.89 & 13.38 & 31.30 & 7.51 & 2.39 & 1.78 & 66.67 \\
\hline & 40 & 31.00 & 13.00 & 70.36 & 14.20 & 27.00 & 7.40 & 2.57 & 1.92 & 61.67 \\
\hline & 80 & 28.33 & 10.00 & 60.55 & 10.25 & 24.65 & 6.71 & 2.46 & 1.50 & 59.33 \\
\hline \multirow{4}{*}{25} & 0 & 27.00 & 12.00 & 68.38 & 12.15 & 34.51 & 10.33 & 1.98 & 1.18 & 61.67 \\
\hline & 20 & 32.00 & 11.33 & 71.46 & 13.18 & 31.34 & 8.53 & 2.28 & 1.51 & 57.67 \\
\hline & 40 & 33.00 & 12.33 & 72.34 & 14.39 & 34.89 & 9.31 & 2.07 & 1.56 & 63.33 \\
\hline & 80 & 30.33 & 13.67 & 74.73 & 12.61 & 35.13 & 9.68 & 2.13 & 1.32 & 58.33 \\
\hline \multirow{4}{*}{50} & 0 & 36.67 & 9.00 & 60.94 & 12.18 & 32.46 & 8.27 & 1.98 & 1.47 & 46.67 \\
\hline & 20 & 34.00 & 13.00 & 66.64 & 12.82 & 32.56 & 9.30 & 2.05 & 1.39 & 47.67 \\
\hline & 40 & 35.67 & 11.33 & 63.29 & 13.32 & 31.12 & 8.02 & 2.03 & 1.41 & 57.33 \\
\hline & 80 & 32.67 & 12.67 & 61.42 & 9.57 & 36.60 & 8.63 & 1.65 & 1.11 & 43.33 \\
\hline \multirow{4}{*}{100} & 0 & 43.00 & 8.00 & 54.86 & 10.27 & 31.06 & 7.80 & 1.77 & 1.32 & 25.67 \\
\hline & 20 & 37.00 & 11.00 & 54.72 & 10.97 & 26.47 & 8.08 & 2.07 & 1.36 & 36.67 \\
\hline & 40 & 37.33 & 10.00 & 58.87 & 11.77 & 32.63 & 8.76 & 1.80 & 1.34 & 37.67 \\
\hline & 80 & 34.33 & 11.00 & 50.01 & 8.26 & 31.64 & 8.35 & 1.58 & 0.99 & 32.69 \\
\hline \multicolumn{2}{|c|}{ L.S.D. at $5 \%$} & 1.71 & 1.65 & 3.62 & 1.33 & 1.11 & 0.31 & 0.12 & 0.07 & 4.07 \\
\hline
\end{tabular}

Additionally, brassinosteroids are involved in many morphological and physiological processes in rice including the elongation and unrolling of leaves and skotomorphogensis (Mori et al., 2002). Therefore, brassinosteroids could be generate erect leaf of rice plant (Morinaka et al., 2006).

\section{Effect of $\mathrm{GA}_{3}$ on flowering:}

Data in Table (4) show that $\mathrm{GA}_{3}$ application significantly decreased the number of days to appearance the first inflorescence. The contrast trend was obtained with numbers, stalk lengths, fresh weight and carotenoides content of inflorescences. Increasing or decreasing character values was related to $\mathrm{GA}_{3}$ concentration. $\mathrm{GA}_{3}$ at $100 \mathrm{mgL}^{-1}$ was more effective on number of days the appearance of the opened first flower and stalk length, $50 \mathrm{mgL}^{-1}$ on diameter, $25 \mathrm{mgL}^{-1}$ on inflorescences fresh weight and carotenoides of flower petals. These effects show that $\mathrm{GA}_{3}$ plays an important role in flowering of marigold plant. That might be due to its clear associations between applied and endogenous GAs and flowering in dicotyledonous species including Arabidopsis (Eriksson et al., 2006). Whereas, the level of bioactive GAs (Variously $\mathrm{GA}_{1}, \mathrm{GA}_{4}, \mathrm{GAs}$ and $\mathrm{GA}_{6}$ ) increase rapidly in the leaf, petiole and shoot apex of both monocots and dicots (King et al., 2006). These results appeared an effect on flowering characters of marigold plant (Menesy et al., 1991). 
J. Agric. Sci. Mansoura Univ., 33 (11), November, 2008

Figs. (3 to 5): Leaf angle of marigold plant under interaction treatments Effect of $\beta$-sitosterol on flowering:

VA० 
Rashad, E. M. et al.

$\beta$-sitosterol application appeared significant decrease on number of days to appearance the first flower and enhancement of inflorescence characteristic (number, diameter, fresh and dry weight) and carotenoids content of flower petioles as shown in Table (5). The lowest value of days number to appearance the first flower and number of inflorescences/plant was more affected by increasing $\beta$-sitosterol concentration. These results show that $\beta$-sitosterol had stimulatory effect on marigold flowering, that meight bedue to flowering hormone role as a steroid or an isoprenoid-like compound. In this trend unsaponifiable liquid fractions from flowering plants promote flowering in the vegetative ones. The active substance might include vitamin $\mathrm{E}$ and certain unidentified sterols (Biswas et al., 1967). This effect appeared at increasing number, fresh and dry weigh of flowers/plant as a result of stigmasterol application on chamomile plant (Abd El- Wahed and Gamal, 2004).

\section{Effect of $\mathrm{GA}_{3}$ and $\beta$-sitosterol interaction on the flowering:}

Data in Table (6) show that interaction between $\mathrm{GA}_{3}\left(100 \mathrm{mgL}^{-1}\right)$ and $\beta$-sitosterol ( $\left.40 \mathrm{mgL}^{-1}\right)$ had significant effect on flowering earliness of marigold plant and increasing number of inflorescences While, $\mathrm{GA}_{3}\left(50 \mathrm{mgL}^{-1}\right)$ plus $\beta$ sitosterol gave the highest value of inflorescence diameter. In the same time, the highest fresh and dry weights of inflorescence were obtained with $\mathrm{GA}_{3}$ (25 mgL-1) and $\beta$-sitosterol $\left(20 \mathrm{mgL}^{-1}\right)$. Carotenoids content in ray flower was more significantly affected by $\mathrm{GA}_{3}\left(25 \mathrm{mgL}^{-1}\right)$ and $\beta$-sitosterol $\left(40 \mathrm{mgL}^{-1}\right)$ interaction treatment.

Table (4): Effect of gibberellic acid on flowering parameters and carotenoids content in ray flowers of marigold plant during full blooming stage (average of the two seasons).

\begin{tabular}{|c|c|c|c|c|c|c|c|}
\hline $\begin{array}{l}\text { Flowering } \\
\text { arameters } \\
\text { Gibberellic Acid } \\
\left(\mathrm{mgL}^{-1}\right)\end{array}$ & $\begin{array}{c}\text { Number } \\
\text { of } \\
\text { days to } \\
\text { first } \\
\text { flower } \\
\text { open }\end{array}$ & $\begin{array}{c}\text { Number of } \\
\text { inflorescences } \\
\text { plant }\end{array}$ & $\begin{array}{c}\text { Stalk length } \\
\text { of } \\
\text { inflorescence }\end{array}$ & $\begin{array}{c}\text { Diameter } \\
\text { of } \\
\text { inflorescence }\end{array}$ & $\begin{array}{c}\text { Fresh weight } \\
\text { of one } \\
\text { inflorescence }\end{array}$ & $\begin{array}{l}\text { Dry weight } \\
\text { of one } \\
\text { Inflorescence }\end{array}$ & $\begin{array}{c}\text { Carotenoids } \\
\text { content in } \\
\text { ray flower } \\
\text { (mg/g D.W. })\end{array}$ \\
\hline Control & 104.6 & 11.50 & 13.57 & 6.86 & 5.46 & 0.78 & 1.374 \\
\hline 25 & 97.8 & 13.93 & 14.81 & 6.54 & 5.54 & 0.77 & 1.461 \\
\hline 50 & 93.3 & 13.42 & 17.19 & 6.93 & 5.41 & 0.73 & 1.254 \\
\hline 100 & 85.7 & 14.82 & 21.52 & 6.59 & 5.42 & 0.75 & 1.263 \\
\hline L.S.D. 5\% & 0.9 & 0.25 & 0.24 & 0.12 & N.S. & 0.01 & 0.038 \\
\hline
\end{tabular}

Table (5): Effect of $\beta$-sitosterol on flowering parameters and carotenoids content in ray flowers of marigold is L. plant during full blooming stage (average of the two seasons).

\begin{tabular}{|c|c|c|c|c|c|c|c|}
\hline $\begin{array}{c}\text { Plewering } \\
\text { parameters }\end{array}$ & $\begin{array}{c}\text { Number } \\
\text { of } \\
\text { days to } \\
\text { first } \\
\text { flower } \\
\text { open }\end{array}$ & $\begin{array}{c}\text { Number of } \\
\text { inflorescences } \\
\text { (mgL-1) }\end{array}$ & $\begin{array}{c}\text { Stalk length } \\
\text { of }\end{array}$ & $\begin{array}{c}\text { Diameter } \\
\text { of } \\
\text { inflorescence }\end{array}$ & $\begin{array}{c}\text { Fresh weight } \\
\text { of one } \\
\text { oflorescence } \\
\text { inflorescence }\end{array}$ & $\begin{array}{c}\text { Dry weight } \\
\text { of one } \\
\text { Inflorescence }\end{array}$ & $\begin{array}{c}\text { Carotenoids } \\
\text { content in } \\
\text { ray flower } \\
\text { (mg/g D.W. })\end{array}$ \\
\hline Control & 99.50 & 13.73 & 16.78 & 6.09 & 4.95 & 0.67 & 1.293 \\
\hline 20 & 97.25 & 13.73 & 16.85 & 7.25 & 5.98 & 0.83 & 1.449 \\
\hline 40 & 91.75 & 14.74 & 16.77 & 6.75 & 5.40 & 0.73 & 1.358 \\
\hline 80 & 92.83 & 11.47 & 16.69 & 6.83 & 5.50 & 0.80 & 1.252 \\
\hline L.S.D. 5\% & 0.94 & 0.25 & N.S. & 0.12 & 0.12 & 0.01 & 0.038 \\
\hline
\end{tabular}


This might be due to the both role of $\mathrm{GA}_{3}$ and $\beta$-sitoserol in enhancing sexual hormone of meristemic tissues that led to earliness and increasing inflorescence characteristic. These results were in agreement with El-Shazly and El-Masri (2003) who found increasing numbers of total and open balls per cotton plant. Bandara and Tanino (1995) showed that $\mathrm{GA}_{3}$ application on carrot plant advanced flowering at least 2 weeks but only increased flowering to $88 \%$. In addition, flowering hormone may be a steroid or isoprenoid-like compound. Other steroid compound play an important role in flowering plant (Biswas et al., 1967).

\section{Effect of $\mathrm{GA}_{3}$ on biochemical contents of marigold leaves:}

Data presented in Table (7) indicated that there are significant increaments of biochemical contents (Chl.a,b Chl.(a+b), carotenoids, total sugar, indoles and free amino acid of marigold leaves related to $\mathrm{GA}_{3}$ (25 $\mathrm{mgL}^{-1}$ ) foliar application. While, total phenols was significantly enhanced with increasing $\mathrm{GA}_{3}$ concentration. Maximum value of total phenols was obtained by the highest concentration of $\mathrm{GA}_{3}\left(100 \mathrm{mgL}^{-1}\right)$. It appears from our results, that increase $\mathrm{GA}_{3}$ concentration led to increase phenolic compounds in marigold leaves. In the opposite trend, the other biochemical contents of marigold plant were improved with $\mathrm{GA}_{3}$ at low concentration. It might be due to that $\mathrm{GA}_{3}$ application resulted in activation of the different enzymes in marigold leave. These results were in accordance of Wu et al . (1993) who found that exogenous gibberellins led to an increase in acid invertase activitygiven the involvement of gibberellins in tulips and the dynamic changes in carbohydrates profiles. Whereas, high concentration of hexose sugar and increased activity of acid invertase were observed when internodes were rapidly elongating (Ranwala and Miller, 2008). In this trend, $\mathrm{GA}_{3}$, treatments increased essential amino acid, total amino acid content of soybean seed (Kushubakova, 2008).

Effect of $\beta$-sitosterol on biochemical contents of marigold leaves:

Biochemical contents of marigold leaves were significantly increased by $\beta$-sitosterol application as shown in Table (8). The highest values of Chl.a, carotenoids, indoles and free amino acids were significantly advanced with $\beta$ sitosterol $\left(40 \mathrm{mgL}^{-1}\right)$ foliar application. While, $80 \mathrm{mgL}^{-1} \beta$-sitosterol gave the maximum value of phenolic compounds in the leaves.

It might be concluded that foliar application of $\beta$-sitosterol concentration was sufficient to improve the biochemical contents of marigold leaves. It seemed that a shift between the previous compounds has been done within and between the plant organs at different stages. This metabolic shift may involved translocation and reconstructed of amino acids (Osaki et al., 1991), activation of dehydrogenase activity (Wang \& Wang, 1997) or stimulation of DNA and RNA replication (Szekers \& Konez, 1998). This might explain the obtained changes in the biochemical contents in the marigold leaves. 
Table (6): Effect of the interaction between gibberellic acid and $\beta$ sitosterol treatments on flowering parameters and carotenoids content in ray flowers of plant during full blooming stage (average of the seasons).

\begin{tabular}{|c|c|c|c|c|c|c|c|c|}
\hline Inter & $\begin{array}{l}\text { Flowering } \\
\text { parameters } \\
\text { ction } \\
\text { eents }\end{array}$ & $\begin{array}{c}\text { No. of } \\
\text { days } \\
\text { to } \\
\text { first } \\
\text { flower } \\
\text { open }\end{array}$ & $\begin{array}{c}\text { No. of } \\
\text { inflorescence/ } \\
\text { Plant }\end{array}$ & $\begin{array}{c}\text { Stalk length } \\
\text { of } \\
\text { inflorescence }\end{array}$ & $\begin{array}{l}\text { Diameter of } \\
\text { inflorescence }\end{array}$ & $\begin{array}{l}\text { Fresh weight } \\
\text { of one } \\
\text { inflorescence } \\
\text { (g) }\end{array}$ & $\begin{array}{c}\text { Dry weight of } \\
\text { one } \\
\text { inflorescence } \\
\text { (g) }\end{array}$ & $\begin{array}{l}\text { Carotenoids } \\
\text { content in } \\
\text { rays } \\
\text { flowers } \\
\text { (mg/g D.W.) }\end{array}$ \\
\hline \multicolumn{9}{|c|}{\begin{tabular}{|l|l|}
$\mathrm{GA}_{3}\left(\mathrm{mgL}^{\prime}\right.$ & $\begin{array}{l}\text { Sitosterol } \\
1\end{array}$ \\
$\left(\mathrm{mgL}^{-1}\right)$
\end{tabular}} \\
\hline \multirow{4}{*}{0} & 0 & 115.00 & 9.00 & 10.92 & 5.25 & 3.87 & 0.62 & 1.069 \\
\hline & 20 & 102.00 & 12.50 & 15.75 & 7.84 & 7.03 & 0.94 & 1.484 \\
\hline & 40 & 96.33 & 15.92 & 14.38 & 7.52 & 5.97 & 0.79 & 1.511 \\
\hline & 80 & 105.00 & 8.58 & 13.25 & 6.82 & 4.99 & 0.76 & 1.431 \\
\hline \multirow{4}{*}{25} & 0 & 98.00 & 16.83 & 15.69 & 6.12 & 5.92 & 0.78 & 1.572 \\
\hline & 20 & 104.00 & 12.79 & 13.52 & 7.36 & 6.79 & 0.95 & 1.438 \\
\hline & 40 & 99.00 & 14.03 & 13.75 & 6.33 & 4.22 & 0.61 & 1.617 \\
\hline & 80 & 90.33 & 12.08 & 16.28 & 6.34 & 5.21 & 0.75 & 1.218 \\
\hline \multirow{4}{*}{50} & 0 & 94.00 & 15.83 & 17.50 & 6.35 & 5.16 & 0.67 & 1.342 \\
\hline & 20 & 98.00 & 13.64 & 16.92 & 7.14 & 5.31 & 0.73 & 1.467 \\
\hline & 40 & 92.00 & 11.28 & 16.80 & 6.69 & 5.67 & 0.70 & 1.047 \\
\hline & 80 & 89.00 & 12.92 & 17.53 & 7.53 & 5.48 & 0.81 & 1.161 \\
\hline \multirow{4}{*}{100} & 0 & 91.00 & 13.25 & 23.00 & 6.63 & 4.84 & 0.61 & 1.188 \\
\hline & 20 & 85.00 & 16.00 & 21.19 & 6.67 & 4.80 & 0.70 & 1.406 \\
\hline & 40 & 79.67 & 17.75 & 22.17 & 6.47 & 5.73 & 0.82 & 1.259 \\
\hline & 80 & 87.00 & 12.28 & 19.72 & 6.61 & 6.32 & 0.89 & 1.199 \\
\hline \multicolumn{2}{|l|}{$5 \%$} & 1.87 & 0.50 & 0.48 & 0.24 & 0.24 & 0.03 & 0.076 \\
\hline
\end{tabular}

Effect of $\mathrm{GA}_{3}$ and $\beta$-sitosterol interaction on biochemical contents of marigold leaves:

Data presented in Table (9) emphasized that biochemical contents in marigold leaves significantly decreased with increasing both $\mathrm{GA}_{3}$ and $\beta$ sitosterol concentration in the interaction treatment as foliar application except the phenolic compounds that significantly enhanced with increasing both two applied substances. Maximum values of the biochemical (Chl.a, carotenoids, total sugars, indoles and free amino acids) were obtained with both $\mathrm{GA}_{3}\left(25 \mathrm{mgL}^{-1}\right)$ plus $\beta$-sitosterol $\left(20 \mathrm{mgL}^{-1}\right)$. It noted that this effect is parallel to $\beta$-sitosterol $\left(40 \mathrm{mgL}^{-1}\right.$ ) result on leaf pigments. It might be due to antagonistic relation between these substances in their interaction. It appears that both gibberellic acid and $\beta$-sitosterol have a role in leave biochemical contents.

This metabolic effect might be due to their precoursor. That is attributing with the balance of both substances in the leave. These results were in line with Abd El-Wahed (2000) on maize, Abd El-Wahed (2008) on soybean who found that sterols compound application improved the biochemical reconstruction in the plants.

Correlation coefficient of growth, flowering and biochemical content of marigold plant:

Correlation coefficient between plant growth, leaf angle, flowering and biochemical contents of marigold leaves related to $\mathrm{GA}_{3}$ effect are presented in in Table (10). The results show highly and positively correlation 
coefficient between leaf angle, plant growth (Fresh weight/plant, and shootroot ratio; flowering (No. of days to first flower) and biochemical contents Chl.(a+b), carotenoids in ray flower, indoles and free amino acids). These effects reflected on the correlation between diameter of inflorescine. From the present results, it could be concluded that $\mathrm{GA}_{3}$ foliar application pronounced increases in growth characters, flowering and biochemical content of marigold leaves.

Concerning of $\beta$-sitosterol foliar application correlation coefficient, the results appeared highly and positively correlation between leaf angle and plant height. While, there are a positive correlation between fresh weight of shoot and diameter of inflorescence and biochemical content except phenolic compound. The interaction between leaf angle and number of days to first flower was significantly attributed with both used substances.

From the results, it be concluded that both substances play an important role in improving marigold plant growth but there is a antagonistic effect between them. This might be due to the same precoursor isoprene.

Table (7): Effect of gibberellic acid on leaf pigments content and some biochemical composition of marigold plant (average of the two seasons).

\begin{tabular}{|c|c|c|c|c|c|c|c|c|}
\hline $\begin{array}{l}\text { Characters } \\
\text { Gibberełic } \\
\text { acid } \\
\left(\mathrm{mgL}^{-1}\right)\end{array}$ & $\begin{array}{c}\text { Chl. a } \\
\text { (mgg }^{-1} \\
\text { F.W) }\end{array}$ & $\begin{array}{c}\text { Chl. b } \\
\left(\mathrm{mgg}^{-1}\right. \\
\text { F.W })\end{array}$ & $\begin{array}{l}\text { Total } \\
\text { Chl } \\
(\mathrm{a}+\mathrm{b}) \\
\left(\mathrm{mgg}^{-1}\right. \\
\text { F.W })\end{array}$ & $\begin{array}{c}\text { Total } \\
\text { Carotenoids } \\
\left(\mathrm{mgg}^{-1} \mathrm{~F} . \mathrm{W}\right)\end{array}$ & $\begin{array}{c}\text { Total } \\
\text { sugars } \\
(\%)\end{array}$ & $\begin{array}{c}\text { Total } \\
\text { indoles } \\
\left(\mathrm{mgg}^{-1}\right)\end{array}$ & $\begin{array}{c}\text { Total free } \\
\text { phenols } \\
\left(\mathrm{mgg}^{-1}\right)\end{array}$ & $\begin{array}{l}\text { Total } \\
\text { free } \\
\text { amino } \\
\text { acids } \\
\left(\mathrm{mgg}^{-1}\right)\end{array}$ \\
\hline Control & 0.38 & 0.25 & 0.63 & 0.52 & 34.02 & 6.055 & 18.92 & 18.70 \\
\hline 25 & 0.36 & 0.27 & 0.64 & 0.55 & 37.72 & & 16.34 & 21.00 \\
\hline 50 & 0.31 & 0.24 & 0.55 & 0.46 & 35.21 & 6.091 & 18.40 & 18.45 \\
\hline 100 & 0.30 & 0.24 & 0.54 & 0.48 & 31.80 & 5.781 & 20.02 & 16.33 \\
\hline L.S.D. 5\% & 0.01 & 0.01 & 0.02 & 0.02 & 0.52 & 0.137 & 0.27 & 0.19 \\
\hline
\end{tabular}

Table (8): Effect of $\beta$-sitosterol on leaf pigments content and some biochemical composition of marigold plant (Average of the two seasons).

\begin{tabular}{|c|c|c|c|c|c|c|c|c|}
\hline $\begin{array}{l}\text { Characters } \\
\text { B-sitosterol } \\
\left(\mathrm{mgL}^{-1}\right)\end{array}$ & $\begin{array}{c}\text { Chl.a } \\
\text { (mgg }^{-1} \\
\text { F.W })\end{array}$ & $\begin{array}{c}\text { Chl.b } \\
\left(\mathrm{mgg}^{-1}\right. \\
\text { F.W })\end{array}$ & $\begin{array}{c}\text { Total } \\
\text { Chl } \\
(\mathrm{a}+\mathrm{b}) \\
\left(\mathrm{mgg}^{-1}\right. \\
\text { F.W })\end{array}$ & $\begin{array}{c}\text { Total } \\
\text { carotenoids } \\
\left(\mathrm{mgg}^{-1} \mathrm{~F} . \mathrm{W}\right)\end{array}$ & $\begin{array}{c}\text { Total } \\
\text { sugars } \\
\left(\mathrm{mgg}^{-1}\right)\end{array}$ & $\begin{array}{c}\text { Total } \\
\text { indoles } \\
\left(\mathrm{mgg}^{-1}\right)\end{array}$ & $\begin{array}{c}\text { Total free } \\
\text { phenols } \\
\left(\mathrm{mgg}^{-1}\right)\end{array}$ & $\begin{array}{c}\text { Total } \\
\text { free } \\
\text { amino } \\
\text { acids } \\
\left(\mathrm{mgg}^{-1}\right)\end{array}$ \\
\hline Control & & 0.26 & 0.56 & & & & & 17.34 \\
\hline 20 & 0.37 & 0.26 & 0.63 & 0.55 & 36.32 & 6.289 & 16.40 & 20.07 \\
\hline 40 & 0.34 & 0.26 & 0.60 & 0.5 & 37.21 & 6.169 & 17. & 19.81 \\
\hline 80 & 0.33 & 0.23 & 0.57 & & 32.58 & 5.891 & & 17.26 \\
\hline L.S.D. 5\% & 0.01 & 0.01 & 0.02 & 0.02 & 0.52 & 0.137 & 0.27 & 0.19 \\
\hline
\end{tabular}


Rashad, E. M. et al.

Table (9): Effect of interaction between gibberellic acid and $\beta$-sitosterol treatments on leaf angle, leaf pigments content and some chemical composition of marigold plant (average of the two seasons).

\begin{tabular}{|c|c|c|c|c|c|c|c|c|c|}
\hline $\begin{array}{l}\text { Interac } \\
\text { treatme }\end{array}$ & Character & $\begin{array}{c}\text { Chl.a } \\
\left(\mathrm{mgg}^{-1}\right. \\
\text { F.W })\end{array}$ & $\begin{array}{c}\text { Chl.b } \\
\left(\mathrm{mgg}^{-1}\right. \\
\text { F.W })\end{array}$ & $\begin{array}{l}\text { Total } \\
\text { Chl. } \\
(\mathrm{a}+\mathrm{b}) \\
\left(\mathrm{mgg}^{-1}\right. \\
\text { F.W })\end{array}$ & $\begin{array}{c}\text { Total } \\
\text { carotenoids } \\
\left(\mathrm{mgg}^{-1} \mathrm{~F} . \mathrm{W}\right)\end{array}$ & $\begin{array}{c}\begin{array}{c}\text { Total } \\
\text { sugars }\end{array} \\
\text { (mgg }^{-1} \\
\text { D.W }\end{array}$ & $\begin{array}{c}\text { Total } \\
\text { indoles } \\
\left(\mathrm{mgg}^{-1}\right. \\
\text { D.W) }\end{array}$ & $\begin{array}{c}\text { Total } \\
\text { phenols } \\
\text { (mgg }^{-1} \\
\text { D.W) }\end{array}$ & \begin{tabular}{|c}
$\begin{array}{c}\text { Total } \\
\text { free }\end{array}$ \\
amino \\
acid \\
$\left(\mathrm{mgg}^{-1}\right.$ \\
D.W)
\end{tabular} \\
\hline $\begin{array}{l}\mathrm{GA}_{3} \\
\left(\mathrm{mgL}^{-1}\right)\end{array}$ & $\begin{array}{l}\text { Sitosterol } \\
\left(\mathrm{mgL}^{-1}\right)\end{array}$ & & & & & & & & \\
\hline & 0 & 0.29 & 0.21 & 0.50 & 0.40 & 27.47 & 5.512 & 23.31 & 15.03 \\
\hline & 20 & 0.42 & 0.27 & 0.68 & 0.56 & 38.71 & 6.818 & 15.19 & 22.91 \\
\hline 0 & 40 & 0.40 & 0.28 & 0.68 & 0.57 & 36.76 & 6.026 & 17.68 & 20.05 \\
\hline & 80 & 0.40 & 0.26 & 0.66 & 0.54 & 33.12 & 5.866 & 19.50 & 16.80 \\
\hline & 0 & 0.36 & 0.32 & 0.68 & 0.59 & 36.61 & 6.179 & 16.70 & 19.40 \\
\hline 5 & 20 & 0.39 & 0.25 & 0.65 & 0.54 & 37.98 & 6.339 & 15.54 & 21.67 \\
\hline 20 & 40 & 0.40 & 0.28 & 0.68 & 0.61 & 41.94 & 6.647 & 14.59 & 23.78 \\
\hline & 80 & 0.31 & 0.24 & 0.55 & 0.46 & 34.75 & 6.085 & 18.55 & 19.16 \\
\hline & 0 & 0.31 & 0.26 & 0.57 & 0.51 & 34.75 & 0.065 & 19.09 & 18.51 \\
\hline 50 & 20 & 0.36 & 0.27 & 0.63 & 0.55 & 35.91 & 6.245 & 16.57 & 18.95 \\
\hline ט & 40 & 0.25 & 0.21 & 0.46 & 0.37 & 36.93 & 6.148 & 17.38 & 18.57 \\
\hline & 80 & 0.31 & 0.22 & 0.52 & 0.43 & 33.22 & 5.907 & 20.55 & 17.77 \\
\hline & 0 & 0.26 & 0.23 & 0.49 & 0.45 & 31.68 & 5.811 & 21.05 & 16.40 \\
\hline & 20 & 0.31 & 0.25 & 0.57 & 0.53 & 32.69 & 5.752 & 18.33 & 16.75 \\
\hline 100 & 40 & 0.31 & 0.26 & 0.57 & 0.48 & 33.22 & 5.856 & 18.91 & 16.84 \\
\hline & 80 & 0.30 & 0.22 & 0.52 & 0.45 & 29.60 & 5.705 & 21.79 & 15.32 \\
\hline L.S.D. & $5 \%$ & 0.01 & 0.01 & 0.02 & 0.02 & 1.03 & 0.275 & 0.54 & 0.39 \\
\hline
\end{tabular}


J. Agric. Sci. Mansoura Univ., 33 (11), November, 2008

10

VA๑V 


\section{Rashad, E. M. et al.}


J. Agric. Sci. Mansoura Univ., 33 (11), November, 2008

12

$\vee \wedge \bullet q$ 


\section{REFERENCES}

Abd El-Wahed, M.S.A. (2000). Effect of stigmasterol, spermidine and sucrose on vegetative growth, carbohydrate distribution and yield of maize plants. Egypt, J. Physiol. Sci., 24: 225-239.

Abd El-Wahed, M.S.A. (2008). Inoculation of Rhizobium jabonicum and $\beta$ sitosterol effect on growth, yield and some biochemical constituents of soybean plant. $35^{\text {th }}$ Ann. Meet. Plant. Grow. Regul. Plant Physiol., No. 39.

Abd El-Wahed, M.S.A. and K.M. Gamal El Din (2004). Stimulation effect of spermidine and stigmasterol on growth flowering, biochemical constituents and essential oil of chamomile plant (Chamomilla recutita L.R). Bulg. J. Plant Physiol., 30: 48-60.

Abd El-Wahed, M.S.; Z.A. Ali, M.S. Ab El-Hady and S.M. Rasha (2001). Physiological and anatomical changes and wheat cultivars as affected by sitosterol. J. Agric. Sci. mansoura Univ., 26: 4823-4839.

A.O.A.C. (1990). Official Methods of Analysis of the Association Official Analytical Chemists. Pub. By the Association of Official Analytical Chemists, Inc., Arlington, West Virginia, USA.

Bandara, P.M.S. and K.K. Tamino (1995). Effect of gibberellic acid $\left(\mathrm{GA}_{3}\right)$ on seeds talk development and flowering in carrot (Daucus carota L. VAR. Sativa DC), ISHS Acta Horticulturae, 1: $394-427$

Bentley, J.A. (1961). Encycl-plant physiol. Ed. By Rubland, W. Vol. XLV: 513 520, Springer-Verlag, Berlin.

Biswas, P.K.; K.B. Paul, J.H.M. Henderson (1967). Effect of steroids on chrysanthemum in relation to growth and flowering. Nature, 213: 917918.

Danial, H.D. and C.M. George (1972). Peach seed dormancy in relation to endogenous inhibitors and applied growth substances. J. Am. Soc. Hort. Sci., 17: 651-654.

Dubois, M.; K.S. Gilles; J. Hamilton; R. Rebers and F. Smith (1956). Colorimetric methods for determination of sugars and related substances. Anal. Chem., 28: 350-356.

Cao, H. and S. Chen (1995). Brassnosteroid induced rice lamina joint inclination and its indole-3-acelic acid and ethylene. Plant Growth Reg., 16(2): 189-196.

Ebrahimzadeh, H.; V. Niknam and A.A. Maasaimi (2001). The sterols of astragalus species from Iran GLC sepatation and quantification. Biochem. Systs Ecol., 29: 393-404.

Edwards, P.A. and J. Enricsson (1999). Sterols and isoprenoids: signal molecules derived from the cholesterol biosynthetic pathway. Annu. Rev. Biochem., 68: 157-185.

El-Shazly, W.M.O. and M.F. El-Masri (2003). Response of Giza 89 cotton cultivar to foliar application of ascorbic acid, gibberellic acid, phosphorus and potassium . J. Agric . Sci ., Mansoura Univ ., 28 : 1579 $-1597$ 
Eriksson, S.; H-Bohlenius, T-Maritz and O. Nilsson (2006). GA 4 is the active gibberellin in the regulation of leafy transcription and Arabidopsis floral initiation. Plant Cell, 18: 2172-2181.

Gomez, K.A. and A.A. Gomez (1984). Statistical Procedures for Agricultural Research pp. $6802^{\text {nd }}$ Ed., John Wiley Sons, Inc. New York.

Hedden, P. and A.L. Phillips (2000). Gibberellin metabolism: new insights revealed by the genes. Trends in Plant Sci. 2000, 5: 523-530.

Howell, W.M.; G.E. Keller, J.D. Kirkpatrick, R.I. Jenkins, R.S. Hunsiger and E.W. McLaughin (2007). Effects of the plant steroidal hormone, 24epibrassinolide, on the mitotic index and growth of onion (Allium cepa) root tips Genet. Mol. Res., 6: 50-58.

Kushubakova, S.L. (2008). Gibberellin effects on soybean yield and quality seed in condition of Kyrgyzstan. $35^{\text {th }}$ Annual Meeting of Plant Growth Regul. Soc. Amer., Aug. 3-7, 2008, No. 5.

King, R.W.; T. Mortiz, J. Martin, F.H. Andersen, I.Kardailsky, C. Blundel and P.M. Chandler (2006). Gibberellin biosynthesis and the regulation of flowering in the long day grass, Lolium temulentum L. by gibberellins and the gene flowering Loclls T. Plant Physiol., 141: 498-507.

Menesy, F.A.; E.M.S. Nofal and E.M. El-Mabrouk (1991). Effect of some growth regulators on Calendula officinalis L. Egypt. J. Appl. Sci. 6(2)115.

Mori, M.; T. Nomura, H. Ooka, M. Ishizaka, T. Yokata, K. Sugimoto and K. Okabe (2002). Isolation and characterization of rice dwarf mutant with a defect in brassinosteroid synthesis. Plant Physiol., 130: 1152-1161.

Morinaka, Y.; T. Sakamato; Y. Inukai and M. Matsuka (2006). Marphological alteration caused by brassionsteroid insensitivity increases the biomass and grain production of rice. Plant Physiol., 141: 924-931.

Nemhauser, J.L.; F.X. Hong and J. Chary (2006). Different plant hormones regulate similar processes through largely nonoverlaping transcriptional responses. Cell, 126: 467-475.

Obsizewski, N.; T. Sun and F. Gubler (2002). Gibberellins signaling: biosynthesis, catabolism and response pathways. Plant Cell, 561-580.

Osaki, M ., T. Shinano and T. Tadano (1991). Redistribution of carbon and nitrogen compounds from the shoot to the harvesting organs during maturation in field crops . Soil. Sci . Plant Nutr ., 37 : 117- 128.

Plummer, D.T. (1978). An introduction to practical Biochemistry $2^{\text {nd }}$ E. P. 144. McGraw-Hill Book Company (UK) Limited London, New York.

Ranwala, A.P. and W.B. Miller (2008). Gibberellin-mediated changes in carbohydrate metabolism during flower stalk elongation in tulips. Plant Grow. Regul., 55: 241-248.

Saric, M.; R. Kastrari, R. Cucic, T. Cupina and I. Gric (1967). Chlorophyll Determinationh. Univerziter U Noveon Sadu Parktickum iz fiziologize Biljaka-Beograd, Hauena Anjiga. pp. 215.

Snedecor, G.W. and W.G. Cochran (1990). Statistical methods Ed. lowa State Univ. Press Ames, lowa, U.S.A.

Sun, T.P. and F, Gubber (2004). Molecular mechanism of gibberellin signaling in plants. Annu. Rev. Plant Biol., 55: 197-223. 


\section{Rashad, E. M. et al.}

Szekeres, M. and C. Konez (1998). Biochemical and genetic analysis of brassinosteroid metabolism and function in Arabidopsis. Plant Physiol. Biochem., 36: 145-155.

Wallenstein, A. and S.A. Luke (1963). Plant morphology: Its control in proserpinaca by photoperiod, emepature and gibberellic acid. Sci. 140: 998-1000.

Wang, S. and S. Wang (1997). Influence of brassinosteroid on rice seedling growth. Intern. Rice Res. 22: 20-21.

Wu , X ., H. Bayle, D. Olson and A. J. Levine (1993). The P53 - m d m - 2 outoregulatory feed back book. Genes \& Dev ., $7: 1126-1132$

\footnotetext{
تأثير البيتاسيتوسيترول وحمض الجبريلليك على زاويـة الورقة و النمو والتزهير والمكونات الكيماوية لنبات الأقحوان

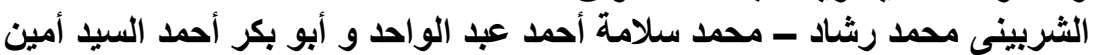$$
\text { قسم النبات ـ المركز القومى للبحوث ـ الدقى ـ القاهرة }
$$

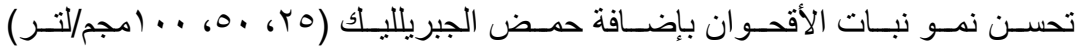

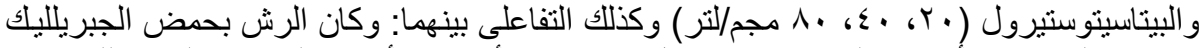

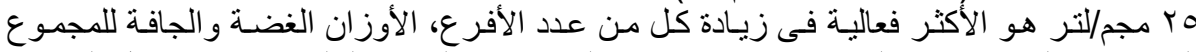

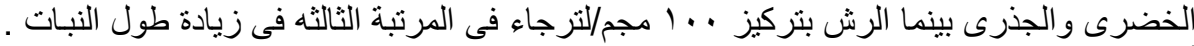

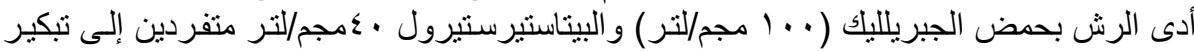

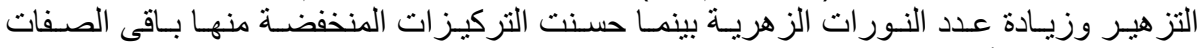

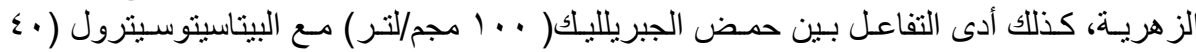

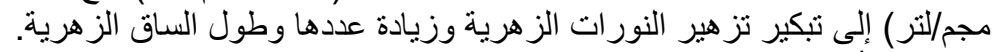

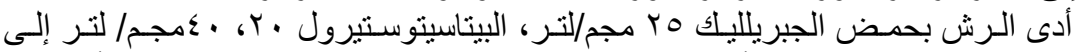

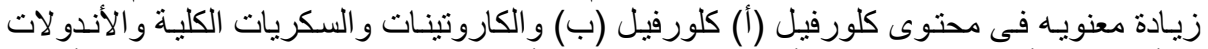

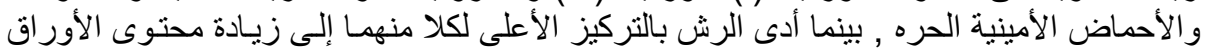

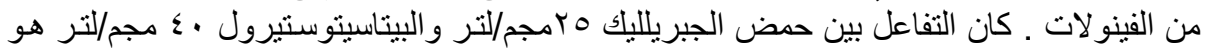

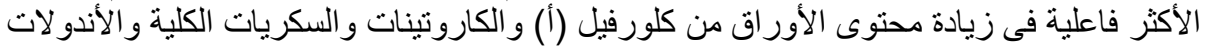

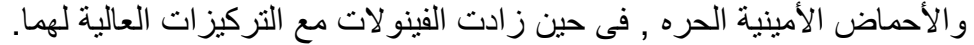

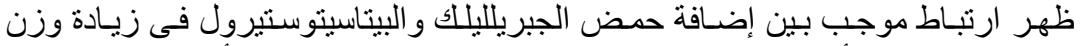
النورات الزهرية وكلورفيل (أ ,_ب)، وارتباط سالب مع محتوى الفينو لات فى الأوراق.
} 
J. Agric. Sci. Mansoura Univ., 33 (11), November, 2008 
J. Agric. Sci. Mansoura Univ., 33 (11): 7845 - 7862, 2008

Table (10): Correlation between growth, flowering and biochemical contents under gibberellic acid concentration

\begin{tabular}{|c|c|c|c|c|c|c|c|c|c|c|c|c|c|c|}
\hline Characters & $\begin{array}{c}\text { Leaf } \\
\text { angle }\end{array}$ & $\begin{array}{c}\text { Plant } \\
\text { height }\end{array}$ & $\begin{array}{c}\text { No. of } \\
\text { branches/plant }\end{array}$ & $\begin{array}{l}\text { Fresh } \\
\text { wt. of } \\
\text { shoots }\end{array}$ & $\begin{array}{c}\text { Shoot- } \\
\text { root } \\
\text { ratio } \\
\text { (F.W.) }\end{array}$ & $\begin{array}{c}\text { No. of } \\
\text { days } \\
\text { to } \\
\text { first } \\
\text { flower }\end{array}$ & $\begin{array}{c}\text { Diameter of } \\
\text { inflorescence }\end{array}$ & $\begin{array}{l}\text { F. wt. of one } \\
\text { inflorescence }\end{array}$ & $\begin{array}{c}\text { Chla } \\
(a+b)\end{array}$ & $\begin{array}{c}\text { Carot. } \\
\text { Content } \\
\text { in ray } \\
\text { flower }\end{array}$ & $\begin{array}{c}\text { Total } \\
\text { carbohydrates } \\
\text { in leaves }\end{array}$ & $\mid \begin{array}{c}\text { Total } \\
\text { indoles } \\
\text { in } \\
\text { leaves }\end{array}$ & \begin{tabular}{|c|} 
Total \\
free \\
phenols \\
in \\
leaves
\end{tabular} & \begin{tabular}{|c|} 
Total \\
free \\
amino \\
acid \\
in \\
leaves
\end{tabular} \\
\hline Leaf angle & 1.000 & & & & & & & & & & & & & \\
\hline Plant height & $-0.986^{* *}$ & 1.000 & & & & & & & & & & & & \\
\hline $\begin{array}{|lr|}\text { No. } & \text { of } \\
\text { branches/plant } \\
\end{array}$ & 0.194 & $|-0.060|$ & 1.000 & & & & & & & & & & & \\
\hline $\begin{array}{l}\text { Fresh weight } \\
\text { of shoots }\end{array}$ & $0.769^{*}$ & $\begin{array}{c}- \\
0.688^{*}\end{array}$ & $0.763^{*}$ & 1.000 & & & & & & & & & & \\
\hline \begin{tabular}{|l|} 
Shoot-root \\
ratio (F.W.) \\
\end{tabular} & $0.965^{* *}$ & $\mid-\overline{-}$ & -0.44 & 0.609 & 1.000 & & & & & & & & & \\
\hline $\begin{array}{l}\text { No. of days to } \\
\text { first flower }\end{array}$ & $0.982^{* *}$ & $\mid-\overline{-}$ & 0.013 & 0.636 & $0.985^{\star *}$ & * 1.000 & & & & & & & & \\
\hline $\begin{array}{l}\begin{array}{l}\text { Diameter of } \\
\text { inflorescence }\end{array} \\
\end{array}$ & 0.259 & -0.202 & -0.255 & -0.116 & 0.221 & 0.352 & 1.000 & & & & & & & \\
\hline $\begin{array}{l}\text { F.W. of one } \\
\text { inflorescence }\end{array}$ & 0.616 & -0.628 & 0.493 & $0.803^{* *}$ & 0.582 & 0.505 & -0.589 & 1.000 & & & & & & \\
\hline Chla $(a+b)$ & $0.899 * *$ & $-0.926^{* *}$ & 0.214 & $0.774^{*}$ & $0.907^{\star \star}$ & 0.856 & -0.178 & $.870^{\star *}$ & 1.000 & & & & & \\
\hline \begin{tabular}{|l|} 
Carot. content \\
in ray flower
\end{tabular} & $0.747^{\star}$ & $-0.761^{*}$ & 0.419 & $0.828^{\star \star}$ & $0.722^{*}$ & 0.655 & -0.446 & $0.983^{* *}$ & $0.946^{\star \star}$ & 1.000 & & & & \\
\hline \begin{tabular}{|l|} 
Total \\
carbohydrates \\
in leaves \\
\end{tabular} & 0.632 & -0.525 & $0.881^{* *}$ & $0.976^{* *}$ & 0.432 & 0.479 & -0.122 & $0.717^{*}$ & 0.620 & $0.717^{*}$ & 1.000 & & & \\
\hline \begin{tabular}{|l|} 
Total indoles \\
in leaves
\end{tabular} & $0.753^{*}$ & -0657 & $0.791^{*}$ & $0.994^{\star \star}$ & $0.575^{\star}$ & 0.619 & -0.038 & $0.735^{\star}$ & $0.717^{\star}$ & 0.764 & $0.986^{\star *}$ & 1.000 & & \\
\hline \begin{tabular}{|lr} 
Total & free \\
phenols & in \\
leaves & \\
\end{tabular} & -0.596 & 0.504 & $-0.879^{\star *}$ & $-0.971^{\star *}$ & $\mid-0.413$ & -0.436 & 0.269 & $-0.800^{\star *}$ & -0.653 & $-0.782^{\star}$ & $-0.988^{\star \star}$ & $-0.966^{* *}$ & 1.000 & \\
\hline $\begin{array}{l}\text { Total free amino } \\
\text { acid in leaves }\end{array}$ & $0.772^{*}$ & $-0.698^{*}$ & $0.748^{*}$ & $0.998^{\star *}$ & 0.621 & 0.640 & -0.152 & $0.830^{* *}$ & $0.796^{*}$ & $0.854^{* *}$ & $0.969^{* *}$ & $0.988^{\star *}$ & $-0.970^{* *}$ & 1.000 \\
\hline
\end{tabular}

Significant at 0.05 level

$* \star$ : Significant at 0.01 level 


\section{J. Agric. Sci. Mansoura Univ., 33 (11), November, 2008}

Table (11): Correlation between growth, flowering and biochemical contents under $\beta$-sitosterol concentration

\begin{tabular}{|c|c|c|c|c|c|c|c|c|c|c|c|c|c|c|}
\hline Characters & $\begin{array}{l}\text { Leaf } \\
\text { angle }\end{array}$ & $\begin{array}{c}\text { Plant } \\
\text { height }\end{array}$ & $\begin{array}{c}\text { No. of } \\
\text { branches/plant }\end{array}$ & $\begin{array}{l}\text { Fresh } \\
\text { wt. of } \\
\text { shoots }\end{array}$ & \begin{tabular}{|} 
Shoot- \\
root \\
ratio \\
(F.W.)
\end{tabular} & $\begin{array}{l}\text { No. of } \\
\text { days } \\
\text { to } \\
\text { first } \\
\text { flower }\end{array}$ & $\begin{array}{c}\text { Diameter of } \\
\text { inflorescence }\end{array}$ & $\begin{array}{l}\text { F. wt. of one } \\
\text { inflorescence }\end{array}$ & $\begin{array}{l}\text { Chla } \\
(a+b)\end{array}$ & \begin{tabular}{|c|} 
Carot. \\
Content \\
in ray \\
flower
\end{tabular} & $\begin{array}{c}\text { Total } \\
\begin{array}{c}\text { carbohydrates } \\
\text { in leaves }\end{array}\end{array}$ & $\begin{array}{c}\text { Total } \\
\text { indoles } \\
\text { in } \\
\text { leaves }\end{array}$ & $\begin{array}{c}\text { Total } \\
\text { free } \\
\text { phenols } \\
\text { in } \\
\text { leaves }\end{array}$ & $\begin{array}{c}\text { Total } \\
\text { free } \\
\text { amino } \\
\text { acid } \\
\text { in } \\
\text { leaves }\end{array}$ \\
\hline Leaf angle & 1.000 & & & & & & & & & & & & & \\
\hline Plant height & $0.885^{\star}$ & 1.000 & & & & & & & & & & & & \\
\hline $\begin{array}{|lr|}\text { Nor } & \text { of } \\
\text { branches/plant }\end{array}$ & -0.242 & 0.197 & 1.000 & & & & & & & & & & & \\
\hline \begin{tabular}{|l|}
$\begin{array}{l}\text { Fresh weight } \\
\text { of shoots }\end{array}$ \\
\end{tabular} & 0.311 & $0.715^{\star}$ & $0.702^{*}$ & 1.000 & & & & & & & & & & \\
\hline \begin{tabular}{|l|} 
Shoot-root \\
ratio (F.W.) \\
\end{tabular} & 0.351 & $0.723^{\star}$ & 0.571 & $0.981^{* *}$ & * 1.000 & & & & & & & & & \\
\hline $\begin{array}{l}\text { No. of days to } \\
\text { first flower }\end{array}$ & 0.066 & -0.235 & $-0.884^{*}$ & -0.472 & -0.296 & 1.000 & & & & & & & & \\
\hline \begin{tabular}{|l|} 
Diameter of \\
inflorescence
\end{tabular} & -0.184 & 0.274 & $0.756^{*}$ & $0.864^{* *}$ & $\star 0.855^{\star}$ & $\star \mid-0.379$ & 1.000 & & & & & & & \\
\hline $\begin{array}{l}\text { F.W. of one } \\
\text { inflorescence }\end{array}$ & -0.193 & 0.236 & 0.638 & $0.820^{*}$ & $0.842^{*}$ & * -0.218 & $0.986^{* *}$ & 1.000 & & & & & & \\
\hline Chla $(a+b)$ & 0.333 & 0.641 & 0.343 & $0.880^{\star \star}$ & ${ }^{*} 0.953^{\star *}$ & 0.001 & $0.806^{*}$ & $0.844^{*}$ & 1.000 & & & & & \\
\hline \begin{tabular}{|} 
Carot. content \\
in ray flower
\end{tabular} & 0.494 & $0.705^{*} \mid$ & 0.126 & $0.780^{*}$ & $0.883^{* *}$ & $* 0.175$ & $0.638^{*}$ & 0.697 & $0.970^{* *}$ & 1.000 & & & & \\
\hline \begin{tabular}{|l|} 
Total \\
carbohydrates \\
in leaves
\end{tabular} & 0.685 & $0.943^{\star *}$ & 0.439 & $0.906^{\star \star}$ & $\star 0.906^{\star *}$ & $*-0.345$ & 0.577 & 0.537 & $0.815^{\star}$ & $0.809^{*}$ & 1.000 & & & \\
\hline $\begin{array}{l}\text { Total indoles } \\
\text { in leaves }\end{array}$ & 0.504 & $0.795^{\star}$ & 0.365 & $0.918^{\star \star}$ & * $0.972^{* \star}$ & $*-0.105$ & $0.735^{\star}$ & $0.749^{\star}$ & $0.974^{* *}$ & $0.961^{* \star}$ & $0.923^{* *}$ & 1.000 & & \\
\hline $\begin{array}{|lr|}\text { Total } & \text { free } \\
\text { phenols } & \text { in } \\
\text { leaves } & \\
\end{array}$ & -0.558 & $-0.842^{*}$ & -0.380 & $-0.924^{* *}$ & $0.968^{* \star}$ & * 0.155 & $-0.704^{*}$ & $-0.706^{*}$ & $0.950^{* *}$ & $-0.941^{* *}$ & $-0.954^{* *}$ & $-0.996^{* *}$ & 1.000 & \\
\hline $\begin{array}{l}\text { Total free aming } \\
\text { acid in leaves }\end{array}$ & 0.605 & $0.882^{* *}$ & 0.394 & $0.925^{\star \star}$ & $\star 0.957^{\star *}$ & * -0.206 & 0.668 & 0.660 & $0.920^{* *}$ & $0.913^{* *}$ & $0.976^{\star *}$ & $0.984^{* *}$ & $\star-0.996^{\star \star}$ & * 1.000 \\
\hline
\end{tabular}

adinintave 0.6050 .882

: Significant at 0.05 level

$*$ : Significant at 0.01 leve 
Rashad, E. M. et al.

Table (12): Correlation between growth flowering, and biochemical contents under interaction treatments

\begin{tabular}{|c|c|c|c|c|c|c|c|c|c|c|c|c|c|c|}
\hline Characters & $\begin{array}{c}\text { Leaf } \\
\text { angle }\end{array}$ & $\begin{array}{c}\text { Plant } \\
\text { height }\end{array}$ & $\begin{array}{c}\text { No. of } \\
\text { branches/plant }\end{array}$ & $\begin{array}{c}\text { Fresh } \\
\text { wt. of } \\
\text { shoots }\end{array}$ & $\begin{array}{l}\text { Shoot- } \\
\text { root } \\
\text { ratio } \\
\text { (F.Wt.) }\end{array}$ & $\begin{array}{c}\text { No. of } \\
\text { days } \\
\text { to } \\
\text { first } \\
\text { flower }\end{array}$ & $\begin{array}{l}\text { Diameter of } \\
\text { inflorescence }\end{array}$ & $\begin{array}{l}\text { F. wt. of one } \\
\text { inflorescence }\end{array}$ & $\begin{array}{l}\text { Chla } \\
(a+b)\end{array}$ & $\begin{array}{c}\text { Carot. } \\
\text { Content } \\
\text { in ray } \\
\text { flower }\end{array}$ & $\begin{array}{c}\text { Total } \\
\text { carbohydrates } \\
\text { in leaves }\end{array}$ & 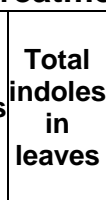 & s $\begin{array}{c}\text { Total } \\
\text { free } \\
\text { phenols } \\
\text { in } \\
\text { leaves }\end{array}$ & $\begin{array}{c}\text { Total } \\
\text { free } \\
\text { amino } \\
\text { acid } \\
\text { in } \\
\text { leaves }\end{array}$ \\
\hline Leaf angle & 1.000 & & & & & & & & & & & & & \\
\hline Plant height & $\left|-0.852^{* *}\right|$ & $\begin{array}{l}+1.000 \\
\end{array}$ & & & & & & & & & & & & \\
\hline $\begin{array}{|lr|}\text { No. } & \text { of } \\
\text { branches/plant }\end{array}$ & 0.019 & -0.027 & 1.000 & & & & & & & & & & & \\
\hline $\begin{array}{l}\begin{array}{l}\text { Fresh weight } \\
\text { of shoots }\end{array} \\
\end{array}$ & 0.432 & -0.159 & 0.583 & 1.000 & & & & & & & & & & \\
\hline \begin{tabular}{|l|} 
Shoot-root \\
ratio (F.Wt.)
\end{tabular} & 0.503 & -0.262 & 0.236 & 0.660 & 1.000 & & & & & & & & & \\
\hline $\begin{array}{l}\text { No. of days to } \\
\text { first flower }\end{array}$ & $0.788^{*}$ & $\star-0.727^{*}$ & -0.307 & 0.124 & 0.367 & 1.000 & & & & & & & & \\
\hline \begin{tabular}{|l|}
$\begin{array}{l}\text { Diameter of } \\
\text { inflorescence }\end{array}$ \\
\end{tabular} & -0.143 & 0.227 & 0.359 & 0.487 & 0.462 & -0.152 & 1.000 & & & & & & & \\
\hline $\begin{array}{l}\text { F.Wt. of one } \\
\text { inflorescence }\end{array}$ & -0.058 & 0.046 & 0.215 & 0.416 & 0.279 & -0.163 & 0.684 & 1.000 & & & & & & \\
\hline Chla $(a+b)$ & 0.423 & -0.358 & 0.305 & 0.659 & $0.706^{\star}$ & * 0.342 & 0.366 & 0.301 & 1.000 & & & & & \\
\hline $\begin{array}{l}\text { Carot. content } \\
\text { in ray flower }\end{array}$ & 0.242 & -0.145 & 0.339 & 0.597 & 0.609 & 0.199 & 0.309 & 0.198 & $0.944^{* *}$ & * 1.000 & & & & \\
\hline \begin{tabular}{|l|} 
Total \\
carbohydrates \\
in leaves
\end{tabular} & 0.332 & 0.042 & 0.478 & $0.870^{* \star}$ & 0.576 & 0.080 & 0.446 & 0.320 & 0.639 & 0.679 & 1.000 & & & \\
\hline $\begin{array}{l}\text { Total indoles } \\
\text { in leaves }\end{array}$ & 0.377 & -0.045 & 0.300 & $0.853^{\star \star}$ & * 0.505 & 0.195 & 0.473 & 0.416 & 0.619 & 0.614 & $0.917^{* *}$ & 1.000 & & \\
\hline \begin{tabular}{|lr} 
Total & free \\
phenols & in \\
leaves & \\
\end{tabular} & -0.306 & -0.019 & -0.471 & $-0.849^{*}$ & -0.615 & -0.069 & -0.450 & -0.393 & $-0.691^{*}$ & * $-0.735^{*}$ & $-0.954^{* *}$ & $-0.898^{\star \star}$ & 1.000 & \\
\hline $\begin{array}{|lr|}\text { Total } & \text { free } \\
\text { amino } & \text { acid in } \\
\text { leaves } & \end{array}$ & 0.453 & -0.108 & 0.388 & $0.894^{\star *}$ & * 0.577 & 0.233 & 0.445 & 0.344 & 0.675 & 0.670 & $0.947^{* *}$ & $0.952^{* *}$ & $* \mid-0.903^{* *}$ & 1.000 \\
\hline
\end{tabular}

Significant at 0.05 leve

$*$ : Significant at 0.01 leve 